\title{
Study of IR Spectrum of the 17 $\beta$-Estradiol using Quantum-Chemical Density Functional Theory
}

\author{
B.F. Minaev, V.A. Minaeva ${ }^{1}$ \\ Cherkassy state technologikal university \\ Shevchenko blvd, 460, Cherkassy,18006, Ukraine \\ ${ }^{1}$ B. KhmelnytskyCherkassy national university \\ Shevchenko blvd, 81, Cherkassy,18031, Ukraine \\ minaeva@cdu.edu.ua
}

\begin{abstract}
The frequency and intensity of IR absorption bands of female sex hormone, 17ß-estradiol, are calculated and assigned using density functional theory with the B3LYP/6-31G ${ }^{* *}$ approach. For a big number of bands such assignment is made for the first time. The frequencies and normal modes of vibrations are predicted in the low-frequency region of the IR spectrum.
\end{abstract}

Key words: 17ß-estradiol, quantum-chemical density functional theory, IR spectra.

Introduction The vibration motion of nuclei in molecules is one of the most important factors which conditions physico-chemical properties and reactivity of substances. The solution for classical equations subject to force filed, discovered from the Schrцdinger's equation in adiabatic approximation, allows determining the forms of vibration of polyatomic molecules as well as their frequencies. The use of these methods in biochemistry of steroid hormones seems the most up to date, as it supplies the possibility to understand the interaction of steroid hormones with the receptors at the microscopic level.

The estrogens are considered to be important regulators of mammalian reproductive function $[1,2]$. They provide embryo formation and development. Biochemical effects of estrogens are realized as a result of their direct influence on the chromosomal apparatus of the cell at the expense of gene expression change and

(C)B.F. MINAEV, V.A. MINAEVA, 2006 the stimulation of RNA synthesis rate (the details of this process are still not clear) [2]. On penetrating the cell membrane the estrogens are initially bound with cytoplasmic receptors, which causes their activation, necessary for their penetration into the nucleus. The process of gene expression begins with transcription, i.e. with the formation of the mRNA precursors and the formation of biologically active mRNAs, which then move to cytoplasm. The mRNA translation on ribosomes results in the synthesis of specific proteins of the cell, which gives grounds for the statement that the cytosolic or direct action mechanism is specific for estrogens.

The study of the reception of steroid hormones is considered to be one of the most important challenges of modern biology and medicine [1]. Especially, the structure of estrogen receptors as well as their interaction with $17 \beta$-estradiol represent a great interest since the cancer diagnostics and treatment are directly 


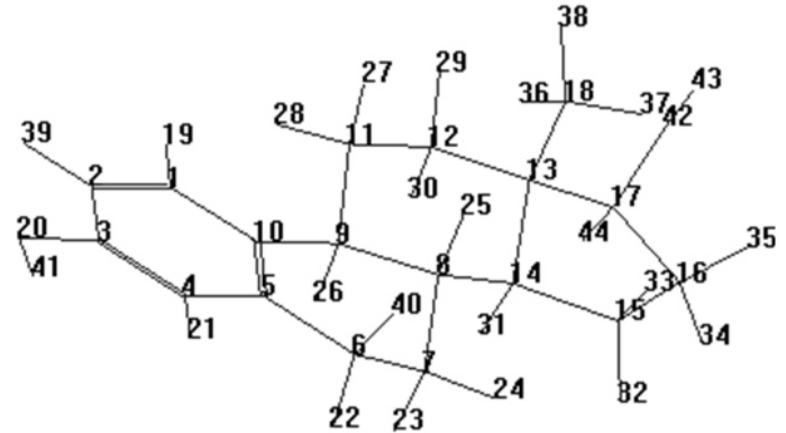

Fig.1 The numeration of atoms in the estradiol molecule

connected to the activity of these receptors and to the level of hormone in blood [3].

Current work presents calculations of frequencies and intensity of vibrations in the IR spectrum of female sex hormone $17 \beta$-estradiol using quantum-chemical method of density functional theory (DFT) [4]. On the basis of these calculations all bands in the IR spectrum of the studied hormone [5] have been assigned. Current analysis is very important not only for the methods development of analytical control of hormones but also for clarifying the nature of their biological activity.

Materials and Methods The geometry of the molecule was calculated step by step, i.e. using the method of molecular mechanics ( $\mathrm{MM}+$ ) and then using the semiempirical self-consistent field method of Hartree-Fok in the framework of PM3 approximation [6]. The results obtained were used for the calculation of equilibrium geometry and vibrational IR spectrum of the studied molecule with the DFT method at the theory level of B3LYP/6-31G** [4,6]. Introduction of polarization functions in the basis set $6-31 \mathrm{G}^{* *}$ allows better account of atomic polarizability in the force field estimation. The calculations were made in the Stockholm Center of Physics, Astronomy, and Biotechnology (SCFAB). The scaling factors used for the frequencies corrections of stretching () vibrations are equal to 0.95 (for the $\mathrm{C}-\mathrm{H}$ and $\mathrm{O}-\mathrm{H}$ bonds), to 0.965 (for the $\mathrm{C}-\mathrm{C}$ bonds in aromatic ring), and to 0.97 (for deformation vibrations). Comparing the calculated forms of normal vibrations with those assignments of the bands in IR spectrum of estradiol described in the literature [3], we were able to appreciate the possibilities of the calculation method used in order to

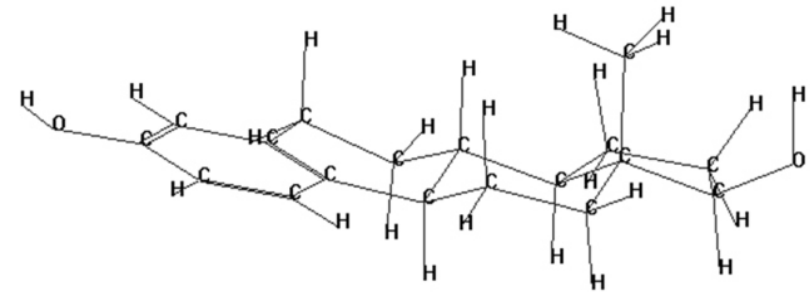

Fig. 2 Conformation of the estradiol molecule optimizing by B3LYP/6-31G** method

predict the frequencies and forms of vibrations as well as the intensity of absorption band in the IR spectra of steroid hormones; to reveal the adjustment value for anharmonicity of vibrations and correlation of electrons (scaling factor) as well as to perform the assignment of those experimental IR bands of estradiol $[3,5]$, the vibrational modes of which are not described in the literature.

Results and Discussion The numeration of atoms in the estradiol molecule is presented in Fig.1, conformation of the molecule obtained as a result of the geometry optimization is presented in Fig.2, some calculated geometrical parameters of the molecule are presented in Table 1. As it can be seen from Fig.2, estradiol molecule consisting of the four condensed rings (phenol (A), two cyclohexanes $(\mathrm{B}, \mathrm{C})$, and cyclopentanol (D)) has a complicated spatial structure. The aromatic ring $\mathrm{A}$ is characterized by a flat organization. The hydroxyl group $\mathrm{O}^{20} \mathrm{H}^{41}$ at the $\mathrm{C}^{3}$ carbon atom and the hydrogen atoms are located in the plain of the A ring (equatorial position), which can be seen in Fig.2 and from the values of dihedral angles (Table 1). The deviation of the hydrogen atoms from the plain of the ring $\mathrm{A}$ does not exceed $0.2^{\circ}$. The cyclohexane rings $\mathrm{B}$ and $\mathrm{C}$ are of an arm-chair form (Fig.2). The calculated valence angles in the cyclohexane rings are close to the tetrahedral ones (Table 2). Hydrogen atoms $\mathrm{H}^{24}, \mathrm{H}^{28}$, and $\mathrm{H}^{29}$ are located in the equatorial position and all the rest hydrogen atoms are in the axial position (directed upwards or downwards). It is worth mentioning also that the lengths of the $\mathrm{C}-\mathrm{H}$ bonds are different, even in the methyl group where the highest length is $\mathrm{C}^{14}-\mathrm{H}^{31}$ 
Table 1.

The bond length, the valence and dihedral angles (grad) in the estradiol molecule, calculated by B3LYP/6-31G** method

\begin{tabular}{|c|c|c|c|}
\hline Parameter & A & Parameter & $\AA$ \\
\hline $\mathrm{C}^{1} \mathrm{C}^{2}$ & 1.390 & $\mathrm{C}^{17} \mathrm{O}^{42}$ & 1.419 \\
\hline$C^{2} C^{3}$ & 1.397 & $\mathrm{O}^{42} \mathrm{H}^{43}$ & 0.967 \\
\hline $\mathrm{C}^{3} \mathrm{C}^{4}$ & 1.394 & $C^{1} C^{2} C^{3}$ & 119.3 \\
\hline $\mathrm{C}^{4} \mathrm{C}^{5}$ & 1.401 & $\mathrm{C}^{2} \mathrm{C}^{3} \mathrm{C}^{4}$ & 119.3 \\
\hline $\mathrm{C}^{1} \mathrm{C}^{10}$ & 1.405 & $C^{3} C^{4} C^{5}$ & 121.4 \\
\hline$C^{5} C^{10}$ & 1.409 & $\mathrm{C}^{4} \mathrm{C}^{5} \mathrm{C}^{10}$ & 119.9 \\
\hline$C^{5} C^{6}$ & 1.519 & $\mathrm{C}^{1} \mathrm{C}^{10} \mathrm{C}^{5}$ & 117.6 \\
\hline $\mathrm{C}^{6} \mathrm{C}^{7}$ & 1.531 & $\mathrm{C}^{6} \mathrm{C}^{7} \mathrm{C}^{8}$ & 110.2 \\
\hline $\mathrm{C}^{7} \mathrm{C}^{8}$ & 1.533 & $\mathrm{C}^{7} \mathrm{C}^{8} \mathrm{C}^{9}$ & 109.2 \\
\hline $\mathrm{C}^{8} \mathrm{C}^{9}$ & 1.553 & $\mathrm{C}^{1} \mathrm{C}^{2} \mathrm{C}^{3} \mathrm{C}^{4}$ & -0.2 \\
\hline $\mathrm{C}^{9} \mathrm{C}^{10}$ & 1.531 & $\mathrm{C}^{1} \mathrm{C}^{2} \mathrm{C}^{3} \mathrm{O}^{20}$ & 180.0 \\
\hline $\mathrm{C}^{9} \mathrm{C}^{11}$ & 1.548 & $C^{2} C^{3} C^{4} C^{5}$ & 0.3 \\
\hline$C^{11} C^{12}$ & 1.543 & $C^{4} C^{5} C^{10} C^{1}$ & -0.5 \\
\hline $\mathrm{C}^{12} \mathrm{C}^{13}$ & 1.535 & $\mathrm{C}^{3} \mathrm{C}^{4} \mathrm{C}^{5} \mathrm{C}^{10}$ & 0.1 \\
\hline$C^{13} C^{14}$ & 1.549 & $\mathrm{C}^{4} \mathrm{C}^{3} \mathrm{C}^{20} \mathrm{H}^{41}$ & 0.2 \\
\hline $\mathrm{C}^{14} \mathrm{C}^{15}$ & 1.544 & $\mathrm{C}^{2} \mathrm{C}^{3} \mathrm{C}^{4} \mathrm{H}^{21}$ & -179.7 \\
\hline$C^{15} C^{16}$ & 1.557 & $C^{10} C^{5} C^{6} C^{7}$ & -15.3 \\
\hline $\mathrm{C}^{16} \mathrm{C}^{17}$ & 1.557 & $C^{5} C^{6} C^{7} C^{8}$ & 45.8 \\
\hline $\mathrm{C}^{13} \mathrm{C}^{17}$ & 1.552 & $\mathrm{C}^{6} \mathrm{C}^{7} \mathrm{C}^{8} \mathrm{C}^{9}$ & -64.9 \\
\hline $\mathrm{C}^{3} \mathrm{O}^{20}$ & 1.369 & $C^{8} C^{9} C^{10} C^{5}$ & -21.8 \\
\hline $\mathrm{O}^{20} \mathrm{H}^{41}$ & 0.966 & $C^{14} C^{15} C^{16} C^{17}$ & 6.4 \\
\hline$C^{8} C^{14}$ & 1.530 & $\mathrm{C}^{15} \mathrm{C}^{16} \mathrm{C}^{17} \mathrm{O}^{42}$ & 150.5 \\
\hline
\end{tabular}

$(1.103 \AA)$, the smallest one is $\mathrm{C}^{9}-\mathrm{H}^{26}(1.044 \AA)$. The $\mathrm{D}$ ring has an envelope form, specific for the five-member rings. The $\mathrm{OH}$ group of cyclopentanol ring and the methyl group are located in $\beta$-position.

There are 126 normal vibrations in the IR spectrum of estradiol molecule, which consists of 44 atoms. The calculated forms of normal vibrations, their frequencies, and intensity are presented in Table 2 . The experimentally obtained IR absorption spectrum [5] is presented in Fig. 3 in the following coordinates: transmission, $\%$ - wave number (frequency), $\mathrm{cm}^{-1}$. This spectrum is obtained for a solid sample of estradiol, dispersed in $\mathrm{KBr}$ and pressed into pellets. The numbering of vibrational modes in the IR spectrum [5], corresponding to our interpretation, is presented in Fig.3. We used continuous numbering of all normal modes in accordance to the increase of vibration frequencies. The standard notations for assignment of vibrational modes have been used [6].

The vibrations bands of the hydroxyl groups The characteristic frequencies determined by vibrations of the $\mathrm{O}-\mathrm{H}$ bonds in estradiol molecule, according to our calculations, have to appear at 3630 and $3619 \mathrm{~cm}^{-1}$ (Table 2, vibrational modes number 126 and 125). Calculations show that the stretching vibration of $\mathrm{O}-\mathrm{H}$ group of phenol ring (A) should take place at higher frequency than the vibration of $\mathrm{O}-\mathrm{H}$ groups of cyclopentanol ring (D), though the frequencies differ in $11 \mathrm{~cm}^{-1}$ only.

The intensity of O-H stretching vibration of the cyclopentanol ring is smaller, than that of the phenol. Stretching vibrations of the $\mathrm{O}-\mathrm{H}$ bonds of the experimental IR spectrum [5] (Fig.3) are observed in two broad bands with high absorption intensity at $3432-3422$ and 3266-3256 $\mathrm{cm}^{-1}$, specific for associated $\mathrm{O}-\mathrm{H}$ groups due to the formation of intermolecular hydrogen bonds and a narrow adsorption band at 3631 $\mathrm{cm}^{-1}$, which is specific for free hydroxyl group of alcohols and phenols [7]. As it is seen from Table 2 and Fig.3, the calculated frequencies of normal vibrations of $\mathrm{O}-\mathrm{H}$ bonds (taking into account the scaling factor) are well correlated with the experimental value of the stretching vibration frequency of the non-associated hydroxyl groups.

Reasoning from the fact that the absorption in phenols at the presence of hydrogen bonds of the $\mathrm{O}-\mathrm{H}$...O type takes place at smaller energies (3250-3200 $\left.\mathrm{cm}^{-1}\right)$, than in the secondary alcohols $(3300$ $\mathrm{cm}^{-1}$ ), broad band of absorption at $3446 \mathrm{~cm}^{-1}$ was related by authors of Ref. [3] to stretching vibrations of O-H bond of cyclopentanol ring, and at $3240 \mathrm{~cm}^{-1}$ was related to stretching vibrations of $\mathrm{O}-\mathrm{H}$ bonds of the phenol ring. By comparison of the calculated and experimental data we have supposed that in the solid samples of estradiol the O-H groups of phenol and cyclopentanol rings form intermolecular hydrogen bonds with different energies and therefore the different displacement of $v(\mathrm{OH})$ bands takes place towards the lower frequencies and the rearrangements of vibration modes occurs.

The absorption bands connected with the $\mathrm{C}^{3} \mathrm{OH}$ and $\mathrm{C}^{17} \mathrm{OH}$ vibrations The $\delta(\mathrm{OH})$ band of phenols is typically observed between $1410-1310 \mathrm{~cm}^{-1}[7,8]$. In 
Table 2.

The frequencies $\left(\mathrm{v}, \mathrm{cm}^{-1}\right)$ and the intensity $(I, \mathrm{~km} / \mathrm{mol})$ of normal vibrations in the vibration absorption spectrum of $17 \beta$-estradiol molecule, calculated by $B 3 L Y P / 6-31 G^{* *}$ method

\begin{tabular}{|c|c|c|c|c|}
\hline Type of vibration* & Mode & $v_{\text {cor }}$ & I & $v_{e x p}\left(\mathrm{~cm}^{-1}\right)$ and their assignment \\
\hline$v\left(O^{20}-H\right)$ at $C^{3}$ & 126 & 3630 & 43.7 & $3446\left(v\left(O^{42}-H\right)\right)[3] ; 3432-3422[5] ; 3631[5]$ \\
\hline$v\left(O^{42}-H\right)$ at $C^{17}$ & 125 & 3619 & 9.9 & $3240\left(v\left(O^{20}-H\right)\right)[3] ; 3266-3256[5] ; 3631[5]$ \\
\hline$v_{a s}\left(C^{l}-H\right.$ and $\left.C^{2}-H\right) A$ & 123 & 3039 & 8.3 & $3017,3028 \mathrm{R}(v(C-H) A)[3] ; 3019[5]$ \\
\hline$v\left(C^{A}-H\right) A$ & 122 & 2986 & 27.9 & \\
\hline$v_{a s}\left(C_{2}\right) \boldsymbol{D} ; v_{a s}\left(C^{18} H_{3}\right)$ & 120 & 2955 & 38.1 & $2964\left(v_{a s}\left(C^{18}-H_{3}\right)\right)[3] ; 2959[5]$ \\
\hline$v_{a s}\left(C^{18} H_{3}\right) ; v_{a s}\left(C H_{2}\right) \boldsymbol{D}$ & 119 & 2952 & 50.2 & - \\
\hline$v_{a s}\left(\mathrm{CH}_{2}\right) \boldsymbol{D}$ in the antiphase & 118 & 2936 & 7.8 & $2936\left(v_{a s}\left(\mathrm{CH}_{2}\right) \mathrm{D}\right)[3] ; 2959[5]$ \\
\hline$v_{a s}\left(\mathrm{CH}_{2}\right) \mathrm{C}$ & 117 & 2932 & 47.2 & - \\
\hline$v_{s}\left(\mathrm{CH}_{2}\right) \boldsymbol{D}$ in one phase and weak $v_{a s}\left(\mathrm{CH}_{2}\right) \boldsymbol{B}, \boldsymbol{C}$ & 113 & 2903 & 45.9 & $2907[3]$ \\
\hline$v_{s}\left(C^{18} H_{3}\right) ; n\left(C^{17}-H^{44}\right) ; v_{s}\left(C_{2}\right) \boldsymbol{D}, \boldsymbol{B}$, in the antiphase & 112 & 2897 & 10.2 & \\
\hline$v_{s}\left(C^{18} H_{3}\right) D ; v\left(C^{17}-H^{44}\right) ; v_{s}\left(C H_{2}\right) \boldsymbol{D}$ & 111 & 2895 & 25.0 & $2884,2889 \mathrm{R}\left(v_{s}\left(C^{18} H_{3}\right)\right)[3]$ \\
\hline$v_{s}\left(C^{l l} H_{2}\right.$ and $\left.C^{l 2} H_{2}\right) C$, in the antiphase; $v_{s}\left(C^{l 8} H_{3}\right)$ & 110 & 2890 & 32.4 & \\
\hline$v_{s}\left(C^{l 5} H_{2}, C^{l 6} H_{2}\right) D$, in the antiphase; $v_{s}\left(C H_{2}\right) C ; v\left(C^{l 7}-H^{14}\right)$ & 109 & 2889 & 16.9 & \\
\hline$v_{s}\left(C^{7} H_{2}\right.$ and $\left.C^{6} H_{2}\right) \boldsymbol{B}$, in the antiphase & 108 & 2875 & 39.4 & \\
\hline$v_{s}\left(C^{12} H_{2}\right) ; v\left(C^{17}-H^{44}\right)$ & 107 & 2867 & 25.0 & $2864\left(v_{s}\left(\mathrm{CH}_{2}\right) \mathrm{B}, \mathrm{C}, \mathrm{D}\right)[3] ; 2864[5] ; 2860[5]$ \\
\hline$v_{s}\left(C^{6} H_{2}\right)$ & 106 & 2859 & 25.1 & \\
\hline$\delta\left(b \angle C^{15} H_{2}\right.$ and $\left.\angle C^{16} H_{2}\right)$, in one phase; $\delta_{a s}\left(C^{18} H_{3}\right)$ & 99 & 1488 & 2.4 & - \\
\hline$\delta\left(\mathrm{b} \angle \mathrm{C}^{11} H_{2}\right.$ and $\left.\angle C^{15} H_{2}\right)$, in one phase; $\delta_{a s}\left(C^{18} H_{3}\right)$ & 98 & 1481 & 1.4 & - \\
\hline$\delta\left(\mathrm{b} \angle \mathrm{C}^{15} H_{2}\right.$ and $\left.\angle C^{16} H_{2}\right)$, in one phase; $\delta_{a s}\left(C^{18} H_{3}\right)$ & 97 & 1475 & 5.0 & $1469\left(\delta_{a s}\left(C^{18} H_{3}\right)\right)[3] ; 1469[5]$ \\
\hline$\delta\left(\mathrm{b} \angle \mathrm{CH}_{2}\right) \boldsymbol{B}, \boldsymbol{C}, \boldsymbol{D}$, stronger in $\boldsymbol{C} ; \delta_{a s}\left(C^{a 8} H_{3}\right)$ & 96 & 1465 & 0.8 & $1463\left(\delta\left(\mathrm{CH}_{2}\right) \mathrm{B}, \mathrm{C}, \mathrm{D}\right)[3] ; 1462[5]$ \\
\hline$\delta\left(b \angle \mathrm{CH}_{2}\right) \boldsymbol{B}, \boldsymbol{C}, \boldsymbol{D}$, stronger in $\boldsymbol{B}$ & 95 & 1465 & 2.3 & \\
\hline$\delta\left(\mathrm{b} \angle \mathrm{CH}_{2}\right) \boldsymbol{B}, \boldsymbol{C}, \boldsymbol{D} ; \delta_{a s}\left(C^{18} H_{3}\right)$ & 94 & 1456 & 2.7 & $1457,1456 \mathrm{R}(v(\mathrm{C}-\mathrm{C}-\mathrm{H}) \mathrm{B}, \mathrm{C}, \mathrm{D})[3]$ \\
\hline$\delta\left(\mathrm{b} \angle \mathrm{CH}_{2}\right) \boldsymbol{B}, \boldsymbol{C}, \boldsymbol{D} ; \delta_{a s}\left(C^{18} H_{3}\right) ; v\left(C^{l 1}-C^{l 2}\right)$ & 93 & 1449 & 1.3 & \\
\hline$\delta\left(\mathrm{b} \angle \mathrm{CH}_{2}\right) \boldsymbol{B}$ & 92 & 1446 & 4.5 & \\
\hline$v_{a s}\left(C^{l}=C^{2}, C^{4}-C^{5}\right) A ; \delta\left(b \angle C^{3} O^{20} H\right.$ and $\left.C^{3} C^{2} H\right)$, in the antiphase & 91 & 1437 & 60.2 & $1448(v(\mathrm{C}-\mathrm{C}-\mathrm{H}) \mathrm{A})[3] ; 1449[5]$ \\
\hline$\rho\left(\tau \mathrm{H}^{44} \mathrm{C}^{17} \mathrm{O}^{42} \mathrm{H}^{43}\right) ; \delta(\mathrm{CH}) \mathbf{B}, \mathbf{C}$ & 90 & 1405 & 43.0 & $1442[3] ; 1439 \mathrm{R}[3] ; 1437[3,5]$ \\
\hline$\delta_{s}\left(\omega C^{18} H_{3}\right) ; v\left(C^{8}-C^{14}\right) ; \delta(C H) \boldsymbol{B}, \boldsymbol{C}, \boldsymbol{D}$, stronger in $\boldsymbol{C}$ ring & 89 & 1381 & 10.8 & $1383,1390 \mathrm{R}\left(\delta_{s}\left(C^{18} H_{3}\right)\right)[3]^{* *}$ \\
\hline$\delta_{s}\left(\omega C^{18} H_{3}\right) ; \delta\left(b \angle C H_{2}\right) \boldsymbol{B}, \boldsymbol{C} ; v\left(C^{8}-C^{14}\right) ; \delta(C H) \boldsymbol{B}, \boldsymbol{C}$ & 88 & 1379 & 17.5 & - \\
\hline$\delta\left(\mathrm{b} \angle \mathrm{C}^{3} O^{20} H\right) ; v_{a s}(C-C) \boldsymbol{A}, \boldsymbol{B}, \boldsymbol{C} ; \rho\left(\omega C H_{2}\right) ; \delta(C H) \boldsymbol{B}, \boldsymbol{C}, \boldsymbol{D}$ & 87 & 1356 & 2.0 & $1359\left(\delta\left(\mathrm{O}^{20} H\right)\right)[3] ; 1358[5]$ \\
\hline
\end{tabular}




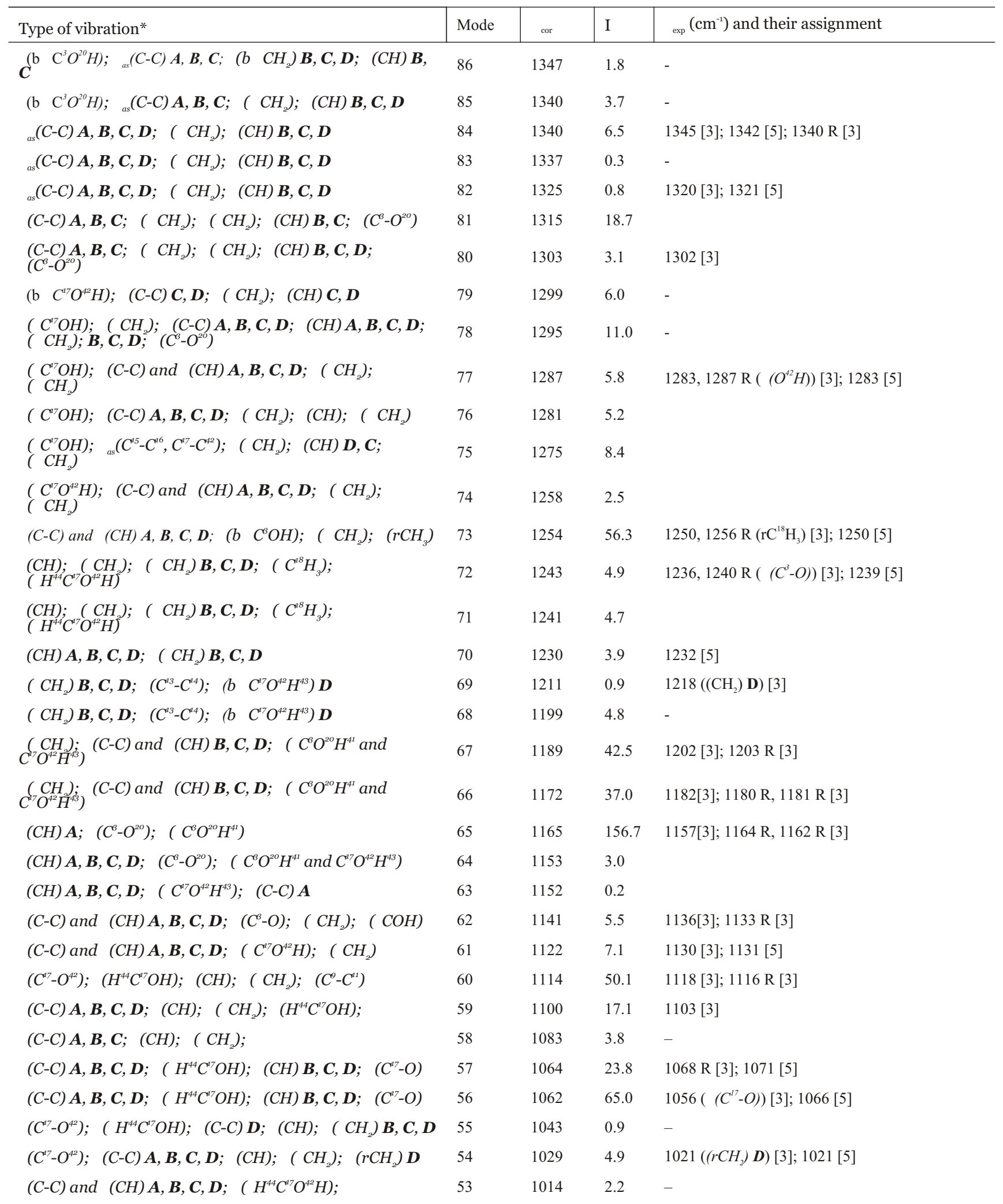


Table 2 continue

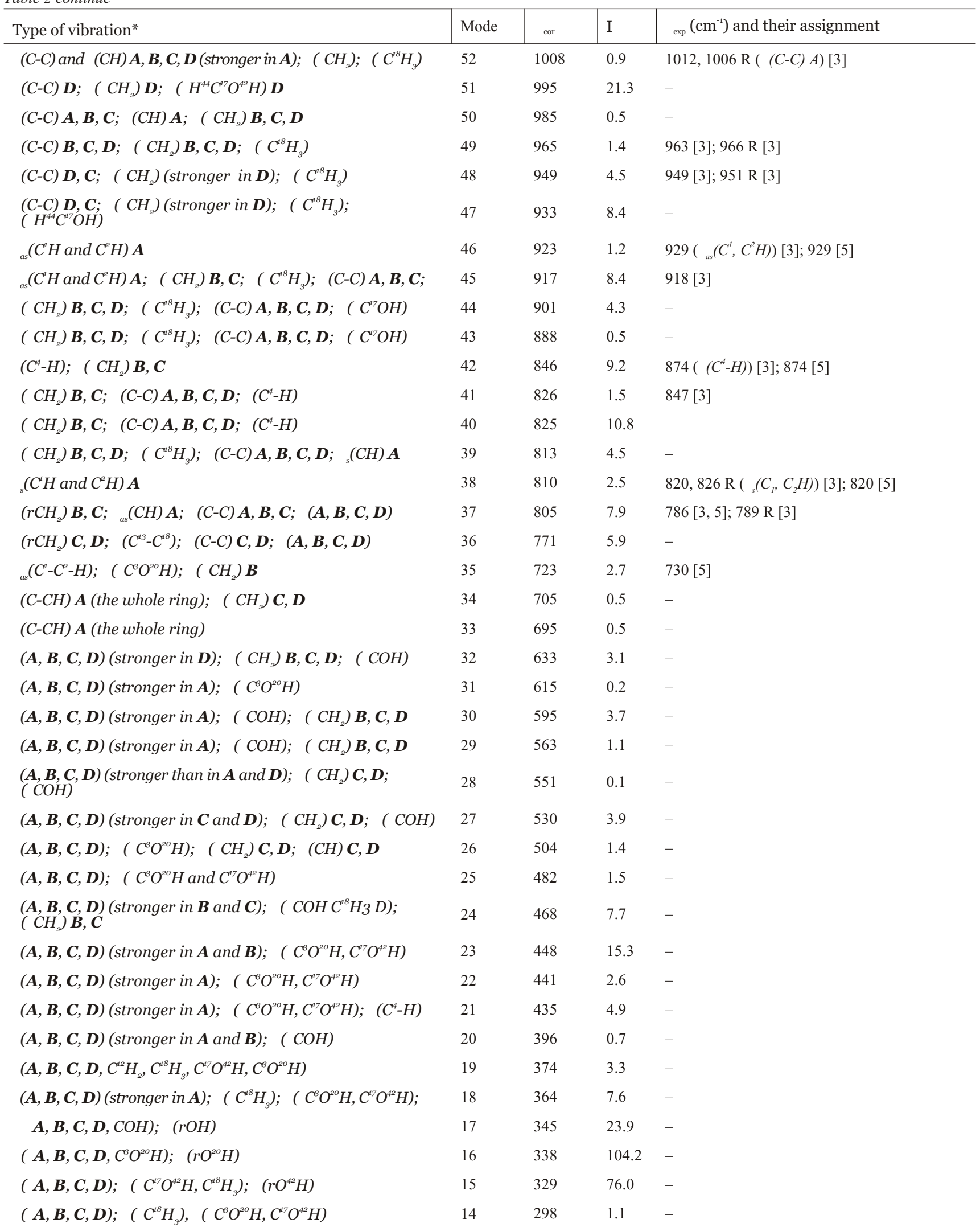




\begin{tabular}{|c|c|c|c|c|}
\hline Type of vibration* & Mode & $v_{\text {cor }}$ & I & $v_{\text {exp }}\left(\mathrm{cm}^{-1}\right)$ and their assignment \\
\hline 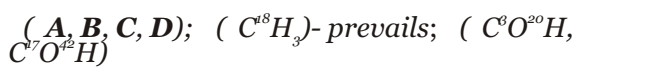 & 13 & 280 & 13.3 & - \\
\hline$\rho(\tau \boldsymbol{A}, \boldsymbol{B}, \boldsymbol{C}, \boldsymbol{D}) ; \rho\left(r O^{42} H\right) ; \rho\left(\tau C^{48} H_{3}\right)$ & 12 & 268 & 1.9 & - \\
\hline$\rho\left(\tau C^{48} H_{3}\right)$ & 11 & 239 & 2.5 & - \\
\hline$\rho\left(\tau C^{48} H_{3}\right) ; \rho\left(\tau C^{47} O^{42} H\right)$ & 10 & 232 & 2.2 & - \\
\hline$\rho(\tau \boldsymbol{A}, \boldsymbol{B}, \boldsymbol{C}, \boldsymbol{D}) ; \rho\left(\tau C^{48} H_{3}\right) ; \rho\left(\tau C^{8} O^{20} H, C^{47} O^{42} H\right)$ & 9 & 230 & 0.4 & - \\
\hline$\left.\rho(\tau \boldsymbol{A}, \boldsymbol{B}, \boldsymbol{C}, \boldsymbol{D}) ; \delta(\mathrm{CH}) \boldsymbol{A} ; \rho\left(\tau C \mathrm{CH}_{2}\right) \boldsymbol{B}, \mathrm{C}^{8} \mathrm{O}^{20} \mathrm{H}, \mathrm{C}^{48} \mathrm{H}_{3}\right)$ & 8 & 207 & 0.3 & - \\
\hline$\rho(\tau \boldsymbol{A}, \boldsymbol{B}, \boldsymbol{C}, \boldsymbol{D}) ; \rho\left(\tau C^{48} H_{3}\right) ; \rho\left(\tau C^{47} O^{42} H\right) ; \rho\left(\tau C H_{2}\right) \boldsymbol{C}$ & 7 & 203 & 0.3 & - \\
\hline$\rho(\tau \boldsymbol{A}, \boldsymbol{B}, \boldsymbol{C}, \boldsymbol{D}) ; \rho\left(\tau C^{48} H_{3}\right) ; \rho\left(\tau C^{47} O^{42} H\right) ; \rho\left(\tau C H_{2}\right) \boldsymbol{C}$ & 6 & 161 & 0.5 & - \\
\hline$\rho\left(\tau \boldsymbol{A}, \boldsymbol{B}, \boldsymbol{C}, \boldsymbol{D}, C^{48} H_{3}, C^{6} O^{20} H, C^{47} O^{42} H, C^{45} H_{2}, C^{46} H_{2}\right)$ & 5 & 126 & 0.8 & - \\
\hline$\rho\left(\tau \boldsymbol{A}, \boldsymbol{B}, \boldsymbol{C}, \boldsymbol{D}, C^{48} H_{3}, C^{6} \mathrm{O}^{20} \mathrm{H}, \mathrm{C}^{47} \mathrm{O}^{42} \mathrm{H}, \mathrm{C}^{45} \mathrm{H}_{2}, \mathrm{C}^{46} \mathrm{H}_{2}\right)$ & 4 & 119 & 0.1 & - \\
\hline$\rho\left(\tau \boldsymbol{A}, \boldsymbol{B}, \boldsymbol{C}, \boldsymbol{D}, C^{48} H_{3}, C^{8} O^{20} H, C^{47} O^{42} H\right)($ stronger in $\boldsymbol{A})$ & 3 & 100 & 1.0 & - \\
\hline$\rho\left(\tau \boldsymbol{A}, \boldsymbol{B}, \boldsymbol{C}, \boldsymbol{D}, C^{48} H_{3}, C^{8} O^{20} H, C^{47} O^{42} H\right)($ stronger in $\boldsymbol{A})$ & 2 & 60 & 0.1 & - \\
\hline$\rho\left(\tau \boldsymbol{A}, \boldsymbol{B}, \boldsymbol{C}, \boldsymbol{D}, C^{48} H_{3}, C^{8} O^{20} H, C^{47} O^{42} H\right)$ & 1 & 32 & 0.1 & - \\
\hline
\end{tabular}

Note: $* v$-valence vibration (stretching of bonds); $\rho$ - external deformational vibration; $(\omega$ - wagging, $r$ - rocking, $\tau$ - torsional and twisting); $\delta$ internal deformational vibration (valence angle change) $\left(b-\right.$ scissors, $\omega-$ umbrella); ${ }^{* *}[3]$ the vibrations are divided into stretching $(v)$ and deformational $(\delta)$

Ref. [3] the experimental band of absorption around $1359 \mathrm{~cm}^{-1}$ was assigned to the deformation vibrations of $\mathrm{OH}$-groups of phenol ring in the IR spectrum. Our calculations show that vibration modes $87-85$ of low intensity with the frequencies of 1356, 1347, and 1340 $\mathrm{cm}^{-1}$ are determined by deformation vibrations of the $\mathrm{O}^{20} \mathrm{H}$ group in the plain of the A ring (a change of the valence angle $\mathrm{C}^{3} \mathrm{O}^{20} \mathrm{H}$ ), which are mixed up with asymmetric stretching vibrations of the $\mathrm{C}-\mathrm{C}$ bonds of carbon skeletal and deformation vibrations of $\mathrm{CH}_{2}-$ and $\mathbf{C H}$-groups of the $\mathbf{B}, \mathbf{C}$, and $\mathbf{D}$ rings.

The $\delta(\mathrm{OH})$ bands of the secondary alcohols are typically observed in the area of $1350-1260 \mathrm{~cm}^{-1}[7,8]$. In Ref. [3] the absorption band in estradiol IR spectrum at $1283 \mathrm{~cm}^{-1}$ (in the Raman spectrum at $1287 \mathrm{~cm}^{-1}$ (in dimethylphormamide) and at $1289 \mathrm{~cm}^{-1}$ (in acetone)) was considered to be $\delta(\mathrm{OH})$ vibration in the cyclopentanol ring. Our calculations have shown that the vibration mode number 79 with the calculated frequency of $1299 \mathrm{~cm}^{-1}$ belongs to deformational vibrations of the $\mathrm{OH}$-group at the carbon atom $\mathrm{C}^{17}$, mixing up with the skeletal vibrations of $\mathrm{C}-\mathrm{C}$ bonds of the $\mathrm{C}$ and $\mathrm{D}$ rings as well as deformation vibrations of the $\mathrm{CH}_{2}$ - and $\mathrm{CH}$-groups of these rings. Vibrational modes 78-74 correspond to torsional vibrations of the
$\mathrm{C}^{17} \mathrm{OH}$ group, connected with the skeletal vibrations in the $\mathbf{D}$ ring. Skeletal vibrations (modes 78-76) are also observed in the $\mathbf{A}, \mathbf{B}$, and $\mathbf{C}$ rings. Skeletal vibrations of the rings (modes 78-74) are mixed up with the deformational twisting and wagging vibrations of $\mathrm{CH}_{2}$-groups of the $\mathbf{B}, \mathbf{C}$, and $\mathbf{D}$ rings and deformational vibrations of the $\mathrm{CH}$-groups. In the experimental spectrum (Fig.3) the vibrational modes 79-75 overlap and the band has got a stronger absorption intensity.

The presence of the C-O polar bond in phenols typically results in occurrence of the intensive absorption band in the range of $1230-1140 \mathrm{~cm}^{-1}$ [7], determined by the participation of this group in the skeletal vibrations. In Ref. [3] only the band with the frequency of $1236 \mathrm{~cm}^{-1}$ is related to stretching vibrations of the $\mathrm{C}^{3}-\mathrm{O}$ bond in estradiol molecule, nevertheless, according to our calculations for the isolated molecule, the absorption in this range is determined by deformational vibrations of $\mathrm{CH}$ - and $\mathrm{CH}_{2}$-groups of the $\mathbf{B}, \mathbf{C}$, and $\mathbf{D}$ rings as well as by twisting vibrations of the $\mathrm{H}^{44} \mathrm{C}^{17} \mathrm{O}^{42} \mathrm{H}$ fragment and methyl group and does not have any contribution from $v\left(\mathrm{C}^{3}-\mathrm{O}\right)$ (vibrational modes 72 and 71). Stretching vibrations of the $\mathrm{C}^{3}-\mathrm{O}$ bond with the frequencies of 1315, 1303, and $1295 \mathrm{~cm}^{-1}$ (modes 81, 80, and 78), 


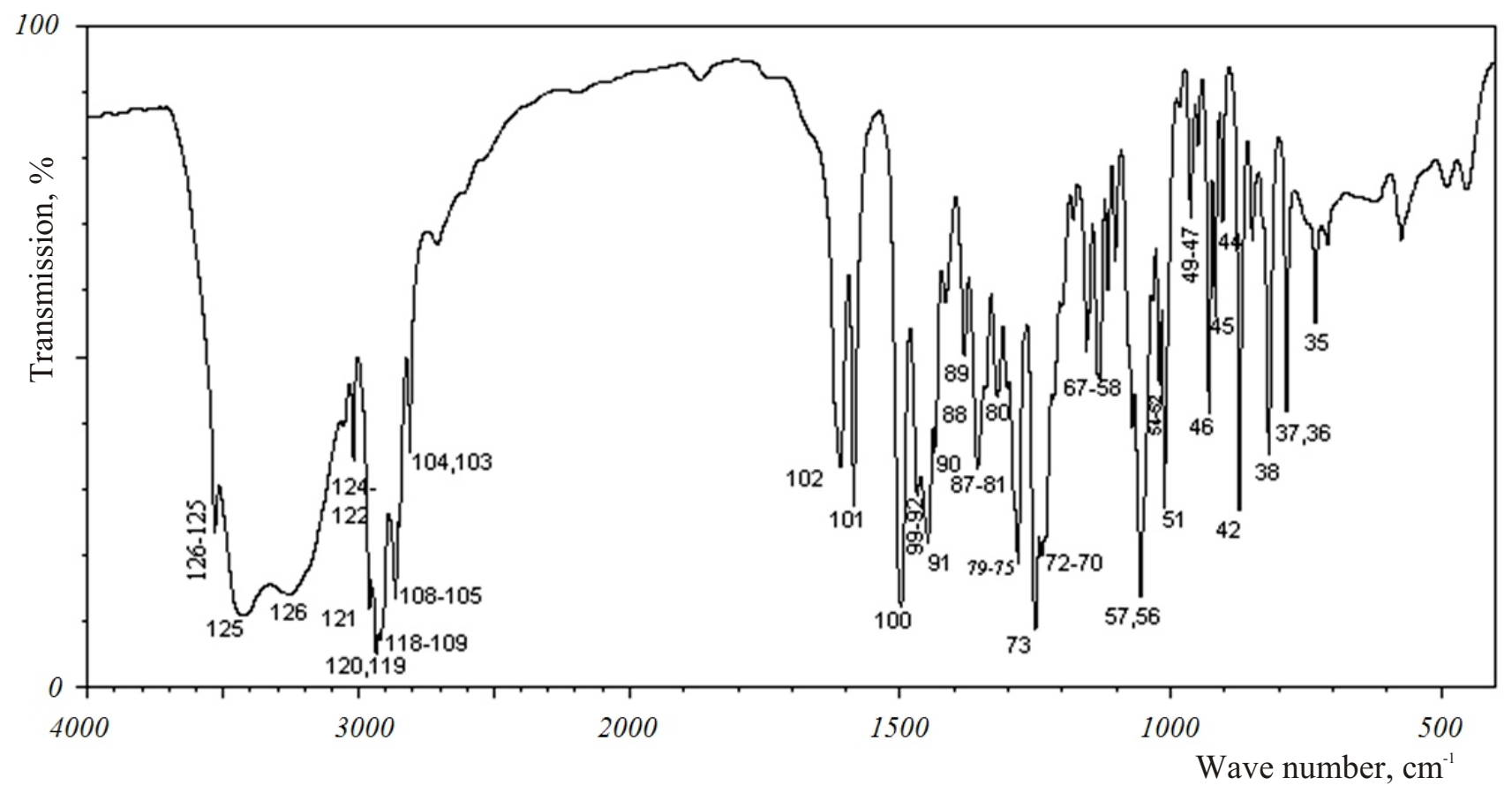

Fig. 3 Estradiol IR spectrum

mixing up with stretching vibrations of $\mathrm{C}-\mathrm{C}$ bonds of the carbon skeleton, by wagging and torsional vibrations of $\mathrm{CH}_{2}$-groups and deformational vibrations of $\mathrm{CH}$-groups of the rings. It is possible that existing intermolecular hydrogen bonds may lead not only to displacement of $v(\mathrm{OH})$ bands but to experimental frequencies of deformational vibrations, bound with $\mathrm{C}-\mathrm{O}-\mathrm{H}$ groups as well. In the vibration mode 65 with the frequency $1165 \mathrm{~cm}^{-1}$ and very high intensity (156.7 $\mathrm{km} / \mathrm{mol}$ ) and in low intensity vibration modes 64,62 stretching bonds $\mathrm{C}^{3}-\mathrm{O}$ mix up with deformational vibrations of $\mathrm{C}-\mathrm{H}$ bond in $\mathrm{A}$ ring and other vibrations (Table 2).

The bands with experimental frequencies 1320 , 1302,1157 , and $1136 \mathrm{~cm}^{-1}$ [3], corresponding in our calculations to the modes $81,80,65,64,62$ and frequencies $1315,1303,1165,1153,1141 \mathrm{~cm}^{-1}$, which have the contribution of stretching vibrations of the $\mathrm{C}^{3}-\mathrm{O}$ bond, in experimental IR spectrum of estradiol, described in Ref. [3], are not of any relation.

The high intensity vibrational modes 60 and 56 with frequencies 1114 and $1062 \mathrm{~cm}^{-1}$ and the mode 55 with very low intensity belong to stretching vibrations of the $\mathrm{C}^{17}$-O bond of cyclopentanol ring, deformational vibrations of the $\mathrm{H}^{44} \mathrm{C}^{17} \mathrm{OH}$ fragment and other vibrations (Table 2). Vibrational mode 54 is also contributed by $v\left(\mathrm{C}^{17}-\mathrm{O}\right)$. The $\mathrm{C}-\mathrm{O}$ absorption band in IR spectra of secondary alcohols is observed between 1125-1030 $\mathrm{cm}^{-1}$ [7-9]. In Ref. [3] the band in IR spectrum with the frequency of $1056 \mathrm{~cm}^{-1}$ was considered to be the stretching vibration of $\mathrm{C}-\mathrm{O}$ bond in the five-member D ring, which corresponds to vibrational mode 56 in our work. The absorption band with the frequency $1118 \mathrm{~cm}^{-1}$ in the IR spectrum of estradiol [3] have not been assigned. In accordance to our data it is defined by stretching vibrations of the $\mathrm{C}^{17}-\mathrm{O}$ bond, and by deformational vibrations of the $\mathrm{H}^{44} \mathrm{C}^{17} \mathrm{OH}$ fragment, of the $\mathrm{CH}$ - and $\mathrm{CH}_{2}$-groups, of the methyl group and by skeletal vibrations of the $\mathrm{C}-\mathrm{C}$ bonds in the cyclohexane ring $\mathbf{C}$ (vibrational mode 60). In the IR spectrum [5] (Fig.3) this band is located in the area of the crowded bands with low absorption intensity.

Absorption bands, connected with vibrations of atoms in the substituted aromatic ring As it is known [7, 8] aromatic compounds may be found by IR absorption in three areas, i.e. by stretching vibrations of the $\mathrm{C}-\mathrm{H}$ bonds between $3100-3000 \mathrm{~cm}^{-1}$, skeletal 
vibrations of aromatic C-C bonds between 1600-1500 $\mathrm{cm}^{-1}$ with different intensity, and by intense absorption below $900 \mathrm{~cm}^{-1}$, determined by out-of-plane deformational C-H vibrations. As it is seen in Table 2, many vibrational modes depend on vibrations of atoms in the substituted aromatic ring A. The modes 102-101 with frequencies 1611 and $1586 \mathrm{~cm}^{-1}$ are determined by skeletal vibrations of $\mathrm{C}-\mathrm{C}$ bonds of the whole ring, but in vibrational mode $100\left(v_{\text {cal }}=1494 \mathrm{~cm}^{-1}\right)$ the C-C vibrations are observed only in a part of the $\mathbf{A}$ ring, as well as in a part of the $\mathbf{B}$ ring, and besides, an excessive change of the $\mathrm{H}^{19} \mathrm{C}^{1} \mathrm{C}^{2}$ and $\mathrm{H}^{21} \mathrm{C}^{4} \mathrm{C}^{3}$ angles occurs.

In vibration mode $91 \quad\left(v_{\text {cal }}=1437 \mathrm{~cm}^{-1}\right)$ the asymmetric vibrations of aromatic bonds $\mathrm{C}^{1}=\mathrm{C}^{2}$ and $\mathrm{C}^{4}-\mathrm{C}^{5}$ are accompanied by the changes in the valence angles $\mathrm{C}^{3} \mathrm{OH}$ and $\mathrm{C}^{3} \mathrm{C}^{2} \mathrm{H}$. According to our calculations, vibration modes 102, 100, and 91 are of high intensity, and intensity of the mode 101 is below average (Table 2). All absorption bands corresponding the vibrational modes 102-100, and 91 have a higher intensity in the experimental IR spectrum [5]. The absorption band at $1600 \mathrm{~cm}^{-1}$ connected with $v(\mathrm{C}-\mathrm{C})$ of the whole ring is one of the most characteristic ones in the spectra of molecules, containing aromatic ring. The frequency which corresponds to this absorption in benzene molecule, calculated by AM1 and MNDO methods [10] is overestimated significantly and equals 1760 and $1718 \mathrm{~cm}^{-1}$ respectively.

Vibration mode 52 with the frequency $1008 \mathrm{~cm}^{-1}$, also belongs to skeletal vibrations of $\mathrm{C}-\mathrm{C}$ bonds in the substituted aromatic ring (symmetric stretching vibrations of the $\mathrm{C}^{2}-\mathrm{C}^{3}$ and $\mathrm{C}^{3}=\mathrm{C}^{4}$ bonds) and to deformational vibrations. This band in the IR spectrum has to be weak, however, in the Raman (R) scattering of estradiol in dimethylphormamide [3], the corresponding absorption band with the frequency $1006 \mathrm{~cm}^{-1}$ is active.

Stretching vibrations of $\mathrm{C}-\mathrm{H}$ bonds in the substituted aromatic ring of estradiol have to be observed at 3054, 3039, and $2986 \mathrm{~cm}^{-1}$ (vibration modes 124-122) and to be of average intensity. The vibration mode 124 calculated by us is conditioned by symmetric stretching vibrations of $\mathrm{C}^{1}-\mathrm{H}$ and $\mathrm{C}^{2}-\mathrm{H}$ bonds, is not observed in the experimental IR spectra [3, 5], however, it is observed in the CS spectrum in acetone at $3062 \mathrm{~cm}^{-1}$ [3]. Asymmetric stretching vibrations of
$\mathrm{C}^{1}-\mathrm{H}$ and $\mathrm{C}^{2}-\mathrm{H}$ bonds with the frequency of $3039 \mathrm{~cm}^{-1}$ (vibration mode 123) correspond to the band at 3017 $\mathrm{cm}^{-1}$ in the IR spectrum and $3028 \mathrm{~cm}^{-1}$ in the CS spectrum respectively [3]. The absorption band at 2986 $\mathrm{cm}^{-1}$ predicted by us, is conditioned by stretching vibrations of $\mathrm{C}^{4}-\mathrm{H}$ bond in the experimental IR spectra of estradiol was not observed, though it was present in IR spectra of $17 \alpha$-ethinyl estradiol $\left(v_{\text {exp }}=2986 \mathrm{~cm}^{-1}\right)$ [3].

According to our calculations, deformational vibrations of $\mathrm{CH}$ in the substituted aromatic $\mathbf{A}$ ring take place at the energy values which are expected for the substituted forms [7]. The vibration modes $65-58$ and 54-52 are contributed by plain deformational $\mathrm{CH}$ vibrations. Vibration modes $46,45,42-40$, and 38 with the frequencies of $923,917,846-825$, and $810 \mathrm{~cm}^{-1}$, respectively, belong to the out-of-plane $\delta(\mathrm{CH})$ vibrations in the $\mathbf{A}$ ring, i.e. the modes 46 and $45-$ asymmetric deformational $\mathrm{C}^{1} \mathrm{H}$ and $\mathrm{C}^{2} \mathrm{H}$ vibrations, the mode 38 - symmetric deformational vibrations of these groups, and in the vibration modes $42-40$ the $\mathrm{C}^{4} \mathrm{H}$ vibrations prevail.

The corresponding absorption bands in the experimental IR spectrum [3] are observed at $929 \mathrm{~cm}^{-1}$ $\left(\delta_{\text {as }}\left(\mathrm{C}^{1} \mathrm{H}\right.\right.$ and $\left.\left.\mathrm{C}^{2} \mathrm{H}\right)\right) ; 874 \mathrm{~cm}^{-1}\left(\delta\left(\mathrm{C}^{4} \mathrm{H}\right)\right)$ and $820 \mathrm{~cm}^{-1}$ $\left(\delta_{s}\left(\mathrm{C}^{1} \mathrm{H}\right.\right.$ and $\left.\left.\mathrm{C}^{2} \mathrm{H}\right)\right)$. The intensity of the vibration mode 42 does not correspond to the intensity of the absorption band at $874 \mathrm{~cm}^{-1}$ (Fig.3). Vibration modes 39 and 37 are contributed by the out-of-plane deformational vibrations of all $\mathrm{CH}$-groups of the $\mathbf{A}$ ring.

The absorption bands connected with stretching vibrations of the $\mathrm{C}-\mathrm{H}$ bonds in the methyl group and in the $\mathrm{CH}_{2}$ - and $\mathrm{CH}$-groups of the cyclohexane and cyclopentanol rings According to our calculations, stretching vibrations of the $\mathrm{C}-\mathrm{H}$ bonds in methyl group and in the $\mathrm{CH}_{2}$ - and $\mathrm{CH}$-groups of the cyclohexane and cyclopentanol rings have to take place between 2978 and $2807 \mathrm{~cm}^{-1}$. In the experimental spectrum [5], the absorption in this area is revealed in the form of a complicated band (Fig.3). The intense vibration modes 121,120 , an 119 with the frequencies of 2978,2955 , $2952 \mathrm{~cm}^{-1}\left(v_{\text {exp }}=2964 \mathrm{~cm}^{-1}\right.$ [3]) belong to asymmetric stretching vibrations of $\mathrm{C}-\mathrm{H}$ in the methyl group, and to the modes 112-110 with the frequencies of 2897, 2895, $2890 \mathrm{~cm}^{-1}$ which belong to symmetric vibrations. In the vibration mode 112 the stretching vibrations of $\mathrm{C}-\mathrm{H}$ 
bonds in the methyl group are mixed up with those of $\mathrm{C}$ - $\mathrm{H}$ bonds in $\mathrm{CH}_{2}$-groups and in $\mathrm{C}^{17}$ - $\mathrm{H}$-group in the cyclopentanol $\mathbf{D}$ ring. According to scientific literature data, the specific infrared frequencies of asymmetric stretching vibrations of C-H methyl group are located between 2975 and $2950 \mathrm{~cm}^{-1}$, and asymmetric ones between 2885 and $2860 \mathrm{~cm}^{-1}[7,8]$.

Vibration modes 120, 119, and 118 with the frequencies of 2955, 2952, and $2936 \mathrm{~cm}^{-1}$ are determined by asymmetric stretching vibrations of the $\mathrm{C}-\mathrm{H}$ bonds in $\mathrm{CH}_{2}$-groups of the cyclopentanol ring. The $v_{\text {as }}(\mathrm{C}-\mathrm{H})$ in $\mathrm{CH}_{2}$-groups of the cyclohexane rings take place at lower energies (vibration modes 117-114 with the frequencies of 2932-2906 $\mathrm{cm}^{-1}$ ). The corresponding symmetric stretching vibrations (vibration modes 113-106 and $v_{s}\left(\mathrm{C}^{7} \mathrm{H}_{2}\right)$ in the vibration mode 114) have to be observed between 2906 and 2859 $\mathrm{cm}^{-1}\left(v_{\text {exp }}=2864 \mathrm{~cm}^{-1}\right.$ [3]). Vibration modes, determined by stretching vibrations of $\mathrm{C}-\mathrm{H}$ bonds in $\mathrm{CH}_{2}$-groups, are quite intense (Table 2). Specific frequencies of asymmetric stretching vibrations of $\mathrm{C}-\mathrm{H}$ methyl groups are located between 2940 and $2915 \mathrm{~cm}^{-1}$, and the asymmetric ones between 2870 and $2845 \mathrm{~cm}^{-1}$ [7].

Stretching vibrations of C-H-groups have a lower intensity in comparison with the similar vibrations of $\mathrm{C}$-H-bonds in $\mathrm{CH}_{2}$-groups (Table 2). The modes 105-103 with the frequencies of 2853, 2817, and 2807 $\mathrm{cm}^{-1}$ are conditioned by stretching vibrations of $\mathrm{C}$-H-groups of cyclohexane rings. The absorption band in the experimental IR spectrum [5], corresponding to vibration mode 105 , is covered by a more intense band, determined by the vibration modes 108-106. Stretching vibrations of $\mathrm{C}^{17}-\mathrm{H}^{44}$ in the $\mathbf{D}$ ring take place at higher energies (modes 112, 111, 109, and 107). The data from Table 2 show that the frequencies of stretching vibrations of $\mathrm{C}-\mathrm{H}$ depend on the type of hybridization of carbon atom. It is determined by the fact that the polarity (and strength) of $\mathrm{C}\left(\mathrm{sp}^{2}\right)-\mathrm{H}$ (in the $\mathbf{A}$ ring) is higher than in $\mathrm{C}\left(\mathrm{sp}^{3}\right)-\mathrm{H}$ (in the $\mathbf{B}, \mathbf{C}, \mathbf{D}$ rings).

The absorption bands, connected with the deformational vibrations of methyl group, $\mathrm{CH}_{2}$ - and CH-groups of cyclohexane and cyclopentanol rings Asymmetric deformational vibrations of methyl group are typically observed between 1470 and $1435 \mathrm{~cm}^{-1}$ [7, $8]$. The calculations performed testify that low intensity vibration modes 99-96, 94, 93 with the frequencies
$1488-1465,1465,1449 \mathrm{~cm}^{-1}$ correspond to asymmetric deformational vibrations of methyl group, mixing up with deformational scissors vibrations of $\mathrm{CH}_{2}$-group of the cyclopentanol and cyclohexane rings. Vibration mode 93 has contribution of stretching vibrations of the carbon skeletal $\mathrm{C}^{11}-\mathrm{C}^{12}$ (Table 2) and the corresponding band in the IR spectrum at $1457 \mathrm{~cm}^{-1}$ (and in the Raman spectrum at $\left.1456 \mathrm{~cm}^{-1}\right)$ in Ref. [3] is assigned to the $v(\mathrm{C}-\mathrm{C}-\mathrm{H})$ mode of the $\mathbf{B}, \mathbf{C}$, and $\mathbf{D}$ rings. In the experimental IR spectrum of estradiol [5] (Fig.3), the vibration modes 99-92 are overlapped and revealed in the shape of a shoulder on the strong band with the transmittance minimum at $1448 \mathrm{~cm}^{-1}$, determined by the mixing of asymmetric $\mathrm{C}^{1}=\mathrm{C}^{2}$ and $\mathrm{C}^{4}-\mathrm{C}^{5}$ stretching vibrations with the deformational vibrations of the $\mathrm{C}^{3} \mathrm{O}^{20} \mathrm{H}$ and $\mathrm{C}^{3} \mathrm{C}^{2} \mathrm{H}$ fragments (vibration mode 91).

Symmetric deformational vibrations of the methyl group generally take place in the narrow region between 1385 and $1370 \mathrm{~cm}^{-1}$ [7]. In the theoretically calculated vibration spectrum the symmetric deformational vibrations of methyl groups are observed between 1381 and $1379 \mathrm{~cm}^{-1}$; they are mixed with deformational vibrations of the $\mathrm{CH}_{2}$ - and $\mathrm{CH}$-groups in the cyclopentanol and cyclohexane rings and with stretching vibrations of the $\mathrm{C}^{8}-\mathrm{C}^{14}$ carbon skeletal (vibration modes 89,88 ). Table 2 shows that symmetric deformational vibrations of methyl groups have a higher intensity comparing to the asymmetric ones.

Twisting vibrations of methyl group in the range $965-888,813$, and lower than $480 \mathrm{~cm}^{-1}$ are basically determined by skeletal vibrations of the rings. Vibration mode 73 (I=56.3 km/mol) with the frequency of $1254 \mathrm{~cm}^{-1}$ is determined by high amplitude asymmetric vibrations of $\mathrm{C}-\mathrm{C}$ bonds in the A ring, being mixed with the weak skeletal vibrations of $\mathrm{C}-\mathrm{C}$ bonds, wagging vibrations of $\mathrm{CH}_{2}$-groups, deformational vibrations of $\mathrm{CH}$-groups of the $\mathbf{B}, \mathbf{C}$, and $\mathbf{D}$ rings, deformational rocking vibrations of methyl groups and in-plain vibration of the $\mathrm{C}^{3} \mathrm{O}^{20} \mathrm{H}$ fragment (the change of valence angle).

In Ref. [3] the corresponding absorption band $\left(v_{\text {exp }}=1250 \mathrm{~cm}^{-1}\right)$ is considered to be rocking vibrations of the $\mathrm{CH}_{3}$-group. According to Ref. [11], the rocking vibration of methyl group is revealed between 1200 and $800 \mathrm{~cm}^{-1}$.

Scissors vibrations of $\mathrm{CH}_{2}-$ groups are of low intensity and according to our calculations they are to 
be observed between 1488 and $1446 \mathrm{~cm}^{-1}$ (vibration modes 99-92). In Ref. [3] the band at $1463 \mathrm{~cm}^{-1}$ is related to the $\mathrm{CH}_{2}-$ groups, according to our calculations it is determined by the overlapping vibration modes 99-92. In the vibration modes 99-97 and 93 scissors vibrations of the $\mathrm{CH}_{2}$ - groups are mixed with the asymmetric deformational vibrations of methyl group. Scissors vibrations at 1379 and 1347 $\mathrm{cm}^{-1}$, wagging and twisting vibrations between $1356-1241 \mathrm{~cm}^{-1}$, twisting vibrations between 1230 and $530 \mathrm{~cm}^{-1}$, and the deformational vibrations of $\mathrm{CH}$-groups between 1405 and 1230 and between 1172 and $1000 \mathrm{~cm}^{-1}$ are related with skeletal vibrations of the $\mathbf{B}, \mathbf{C}$, and $\mathbf{D}$ rings.

The absorption band at $1218 \mathrm{~cm}^{-1}$ in IR spectrum of estradiol, described in the literature [3], (1220 ( $R$, dimethylphormamide), 1221 ( $\mathrm{R}$, acetone)) and $\mathrm{CH}_{2}$, related to the $\mathbf{D}$ ring, according to our calculations, is connected with the stretching and deformational skeletal vibrations in the $\mathbf{D}$ ring, as well as with the torsional vibrations of $\mathrm{CH}_{2}$-groups of the cyclohexane rings (vibration modes 69,68 ). The intensity of such vibrational modes is low and therefore this band in the IR spectrum [3] is covered by a wide band, determined by the overlap of vibration modes 73-70.

The rocking vibrations of $\mathrm{CH}_{2}$-groups, determined by stretching vibrations of $\mathrm{C}-\mathrm{C}$ bonds of the carbon skeleton, are observed in vibrational modes 37 and 36 with the frequencies of 805 and $771 \mathrm{~cm}^{-1}$, respectively. In experimental IR spectra [3,5], to our mind, they have a corresponding narrow band of middle intensity at 786 $\mathrm{cm}^{-1}$, which has not been assigned in Ref. [3]. Our calculated intensity of these vibration modes is below average.

Absorption bands, connected with the skeletal vibrations Absorption bands corresponding to the vibrations of the skeleton of estradiol molecule, should be revealed in two areas, namely, $1356-771 \mathrm{~cm}^{-1}$ and below $725 \mathrm{~cm}^{-1}$. The first area is determined by stretching vibrations of $\mathrm{C}-\mathrm{C}$ bonds of the carbon skeleton. In the area of $725-435 \mathrm{~cm}^{-1}$ a significant deformation of the rings is observed, and below 400 $\mathrm{cm}^{-1}$ the vibrations, connected with the twisting of the rings are observed. All skeletal vibrations are mixed with other vibration types and are generally not very intense.
Low frequency vibrations One of the advantages of calculation methods in quantum chemistry is the possibility to predict the low frequency vibrations for the hard-to-reach experimental areas. In the range of $633-32 \mathrm{~cm}^{-1}$, there are 32 vibrational modes which form integral absorption area, connected with deformational vibrations for all rings of the carbon skeleton, twisting vibrations of $\mathrm{CH}_{2}$-group of the cyclohexane and cyclopentanol rings, the $\mathrm{C}-\mathrm{O}-\mathrm{H}$ fragments and methyl group. Vibration modes $17-15$ are contributed by rocking vibrations of hydroxyl groups. According to our calculations vibration modes 16 and 15 are of high intensity (104.2 and $76.0 \mathrm{~km} / \mathrm{mol}$, respectively).

The binding of steroid hormone with a receptor is known to be irreversible and non-covalence. Big dipole moments of IR transitions for low frequency vibrations may be responsible for disperse resonance interactions of steroid hormone with a receptor, as well as for the energy transfer between them. High density of low frequency vibrations, to our mind, allows the molecules of hormones to be excited even at body temperature and to provide high activity of hormones and their selectivity during their interaction with the receptor.

Conclusions The calculations performed proved the reliability of the density functional method at the level of B3LYP/6-31G** theory in predicting the number of active vibrations in IR spectra of steroid hormones, their frequencies and forms. The calculated intensities of the vibrational modes in a series of cases do not correlate with the intensities of absorption bands in the observed IR spectrum; this may be connected with the presence of intermolecular interactions, which are not taken into account in the calculations. Beside the explanation of the nature of bands in the IR spectra of steroid hormones, the theoretical calculations of their vibrations should help in understanding the specifics of interaction of hormones with the corresponding receptors. Scrutinizing the question "Which factor determines the specificity of steroid hormones and their ability to bind into the target cells with the receptor forming an active hormone-receptor complex?" we noticed the presence of four rings with specific saturated bonds, which supply multiple low frequency vibrations with a significant contribution made by deformational vibrations of the polar $\mathrm{COH}$ fragments. To our mind, the ability of non-rigid vibration system 
of steroid hormones to resonate with the specific vibrations of protein molecules may provide their affinity with receptor proteins.

Б. Ф. Минаев, В. А. Минаева

Исследование инфракрасного спектра $17 \beta$-эстрадиола квантово-химическим методом

Резюме

Квантово-химическим методом функиионала плотности на уровне

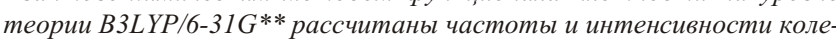
баний в ИК спектре молекулы женского полового гормона 17ß-эстрадиола и выполнено их отнесение. Для многих полос такая интерпретация сделана впервые. Также впервые предсказаны частоты и формы низкочастотных колебаний. Кратко обсуждается биологическое значение полученных результатов.

Ключевые слова: 17ß-эстрадиол, квантово-химический метод функционала плотности, колебательный ИК спектр.

\section{REFERENCES:}

1. Боднар П. М., Комісаренко І. В., Комісаренко Ю. І., Михальчишин Г. П., Периева Т. О., Пішак В. П., Приступюк О. М., Рєзніков О. Г., Рибаков С. Й., Щербак О. В. Ендокринологія / За ред. П. М. Боднара.-К.: Здоров'я, 2003.-512 с.

2. Боєчко Л. О. Основи біохімії вітамінів і гормонів.-Черкаси: Вид-во ЧНУ, 2005.-294 с

3. Barnett S. M., Butler I. S., Top S., Yaouen G. Pressure tuning infrared and solution Raman spectroscopic studies of $17 \beta$-estradiol and several A-ring and $17 \alpha$-ethynylestradiol derivatives // Vibrational Spectrosc.-1995.-8.-P. 263-277.

4. Becke A. D. Density-functional thermochemistry. The role of exact exchange // J. Chem. Phys.-1993. - 98.-P. 5648 - 5655.

5. http://www.aist.go.jp/RIODB/SDBS/ (National Institute of Advanced Industrial Science and Technology, date of access)

6. Пентин Ю. А., Вилков Л. В. Физические методы исследования в химии.-М.: Мир, 2003.-250 с.

7. Казичына Л. А., Куплетская Н. Б. Применение УФ-, ИК-, ЯМР- и масс-спектроскопии в органической химии.-М.: Изд-во Моск. ун-та, 1979.-240 с.

8. Беллами Л. Инфракрасные спектры молекул--М.: ИЛ, 1957.- $444 \mathrm{c}$

9. Zeiss H., Tsutsui M. The carbon-oxygen absorption band in the infrared spectra of alcohols // J. Amer. Chem. Soc.-1953.-76.-P. $897-900$.

10. Healy E. F., Holder A. An evaluation of AM1 calculated vibrational frequencies // J. Mol. Struct. (Theochem).-1993.-128.-P. $141-156$.

11. Драго Р. Физические методы в химии.-М.: Мир, 1981.-1.-С. 190. 